\title{
Modelling and mapping of plant phenological stages as bio-meteorological indicators for climate change
}

\author{
Winfried Schröder*, Gunther Schmidt and Simon Schönrock
}

\begin{abstract}
Background: In Hesse, a federal state in central Germany, the average air temperature of the period 1991 to 2009 was by $0.9^{\circ} \mathrm{C}$ higher compared to that of 1961 to 1990 . A further rise in air temperature of up to $3.7^{\circ} \mathrm{C}$ compared to the reference period 1971 to 2000 is expected until the end of the twenty-first century. This may affect the beginning and length of phenological stages of plants. Hence, this project should analyse and model spatiotemporal trends of plant phenology as being an indicator for climate change-related biological effects. Meteorological data together with data on 35 phenological phases of plants indicating different phenological seasons and observed at 6,500 sites in Germany (553 in Hesse) between 1961 and 2009 were analysed in a GIS. Estimations on phenological developments in the future periods 2031 to 2060 and 2071 to 2100 were based on data from four regional climate models.

Results: Thirty-one out of 35 phases started earlier in the years 1991 to 2009 compared with 1961 to 1990 . These shifts were stronger in Hesse (8 days) than in Germany ( 6 days). As winter phases tend to shift towards the end of the year, a prolongation of the vegetation period of up to 3 weeks was observed. More than $70 \%$ of the phases were correlated with air temperature by $r \geq 0.5$, more than $50 \%$ even by $r \geq 0.7$. Since the 1990 s, phenological shifts and regional differences in phase onsets amplified. In many cases, the shifts between 2071 to 2100 and 1961 to 1990 are expected to be at least twice as high as those between 1991 to 2009 and 1961 to 1990.

Conclusions: The presented approach allows revealing statistical relationships between air temperatures and phenological onsets. Thus, shifts in plant phenology are an appropriate bioindicator to map early signs of ecosystem transitions under climate change. The phenological records allow estimating future trends of plant phenological development. Using phenological maps as presented in this article, efficient adaption strategies may be planned and implemented in terms of, e.g. adjusting delineation, shape and allocation of protected areas.
\end{abstract}

Keywords: Bioindicator; Climate projections; Geostatistics; Phenological shift

\section{Background}

Climate change impacts on individual species comprise shifts in phenology, productivity, distribution and, thus, biodiversity. Therefore, phenological phases are used as indicators for detecting ecological impacts of climate change on flora and fauna such as plants, migratory birds or fishes and, consequently, on ecosystems reflecting the results of manifold combinations of environmental interactions [1]. Changes in the timing of phenological stages

\footnotetext{
* Correspondence: wschroeder@iuw.uni-vechta.de Landscape Ecology, University of Vechta, P.O. Box 1553, Vechta 49364, Germany
}

of plants such as foliation, flowering, fruit ripening, colour changing and leaf fall are recognized as globally coherent ecological fingerprints of climate change. Plant development in terms of phenological stages as exemplified is a rather sensitive bio-meteorological response to environmental variation [2], which is ecologically meaningful since changes in phenophases serve as both forcing and inhibiting ecological processes [3] across spatial scales from individuals to landscapes [4]. Hence, shifts in phenology might be of importance for the implementation of mitigation and adaptation measures in compliance with regulations such as the European Habitat

\section{黑 Springer}


Directive on the one hand [5] and for crop yields and food security issues on the other hand [6,7].

According to the etymologic origin of the term phenology, i.e. the ancient Greek word 'phainestai' meaning 'to appear', which was introduced by [8], plant phenology examines annually and periodically reappearing events in growth and development of plants [9-11]. The study of the timing of recurring biological events encompasses the causes of their timing with regard to biotic and abiotic drivers. The interrelation among the phases of the same or different species is called phenology [12]. Phenology is, thus, an integrative environmental science [13]. Phenological observations corroborated on the one hand that phenological phases can exhibit remarkable interannual variability and large spatial differences due to individual characteristics such as genes and age and environmental factors such as meteorological conditions at the micro- and macro-scale, soil conditions, water supply, diseases, and competition. On the other hand, the seasonal development of plants is, however, mainly influenced by air temperature, photoperiod and precipitation. In particular, spring development in the Northern Hemisphere mid-latitudes mainly depends on the temperatures in winter and spring [14-17].

Recent studies corroborated that the beginning of phenological phases, such as blooming or foliation, is closely related to air temperature [1,2,18-25]. As higher temperatures advance the course of phenological events [26], phenological data reflect biological response to this feature of climate change [27] and, therefore, can be used for climate bio-monitoring [28]. Regarding the sensitivity of spring phenology of plants to warming across temporal and spatial climate gradients in independent databases, [19] found good congruence, despite significant differences in species richness and geographic distribution and concluded that this should encourage 'to move beyond basic statistical diagnosis of trends towards explicit predictions into the future'.

Between 1906 and 2005, the global mean air temperature increased by $0.74^{\circ} \mathrm{C}$ [29]. In Germany, the long-term mean air temperature of the period 1991 to 2009 was $0.9^{\circ} \mathrm{C}$ higher compared to that of the climate reference period of 1961 to 1990. The same holds true for the German federal state Hesse. According to different climate projections and emission scenarios, a further rise of the long-term mean air temperature in Hesse from $9.1^{\circ} \mathrm{C}$ in the period of 1991 to 2009 to $12^{\circ} \mathrm{C}$ at the end of the twenty-first century is expected. Given that background, within a GIS environment, this investigation was focused on(1) the development of measured (1961 to 2009) and projected (2031 to 2060 and 2071 to 2100) air temperatures and phenological observations (1961 to 2009), (2) the spatial variation of the beginning of phenological phases in different natural landscapes, (3) the correlation between air temperatures and the onset of phenological phases and the (4) calculation of maps depicting the spatial patterns of measured (1961 to 2009) and projected (2031 to 2060 and 2071 to 2100) phenological phases.

\section{Results and discussion}

Development of measured (1961 to 2009) and projected (2031 to 2060 and 2071 to 2100) air temperatures and phenological observations (1961 to 2009)

The annual mean air temperatures increased from $8.2^{\circ} \mathrm{C}$ (1961 to 1990) to $9.1^{\circ} \mathrm{C}$ (1991 to 2009) in both Germany and Hesse. Regarding the natural landscapes of Hesse, the regional yearly means range between $7.7^{\circ} \mathrm{C}$ and $10.1^{\circ} \mathrm{C}$ (1961 to 1990) and $8.6^{\circ} \mathrm{C}$ and $10.9^{\circ} \mathrm{C}$ (1991 to 2009). Air temperatures were strongly associated with elevation patterns (Figure 1). Depending on the model used for temperature projection, the long-term annual mean air temperature rise, comparing the reference periods 1971 to $2000\left(8.5^{\circ} \mathrm{C}\right.$ according to measurements and $8.6^{\circ} \mathrm{C}$ according to projections) and 2071 to 2100 , varies between $3.2^{\circ} \mathrm{C}$ (ECHAM5/COSMO-CLM) and $3.7^{\circ} \mathrm{C}$ (WETTREG2010).

Reflecting the measured temperature increase between the periods 1961to 1990 and 1991 to 2009 (Figure 1), 31 of the examined 35 phenological phases advanced towards the beginning of the year as illustrated in Figure 2 for the ten indicator phases. On average, of all the 35 phases, the shifts in Hesse are even stronger (about 8 days) than those in Germany (about 6 days). A lot of phases, especially in Hesse, showed even shifts of more than 10 days. The strongest shifts were detected for phases in spring and early summer. In the further course of the year, some phases, especially in late summer and autumn, show weaker shifts. At the end of the phenological year in late autumn and winter, respectively, some phases even showed a reverse shift towards the end of the year. Along with these phenological shifts, the vegetation period extended. In some Hessian natural land units (Lahn Valley, Westerwald and Odenwald, and Spessart and South Rhoen), the prolongation lasted up to 3 weeks (Figure 3).

\section{Correlation between air temperature and plant phenology}

The development of the measured (1961 to 2009) air temperatures and phenological observations as exemplarily depicted in Figure 4 for the beginning of flowering of Malus domestica (phase 62) was quantified by the use of Pearson's correlation coefficients (Table 1) quantifying the strength of the statistical association between the onset of the phenophases and air temperatures during those months with highest correlations. For phase 62 (apple bloom), the maximum correlation coefficient was calculated for the months March to June in the years 1971 to 2000 , amounting to -0.87 . 


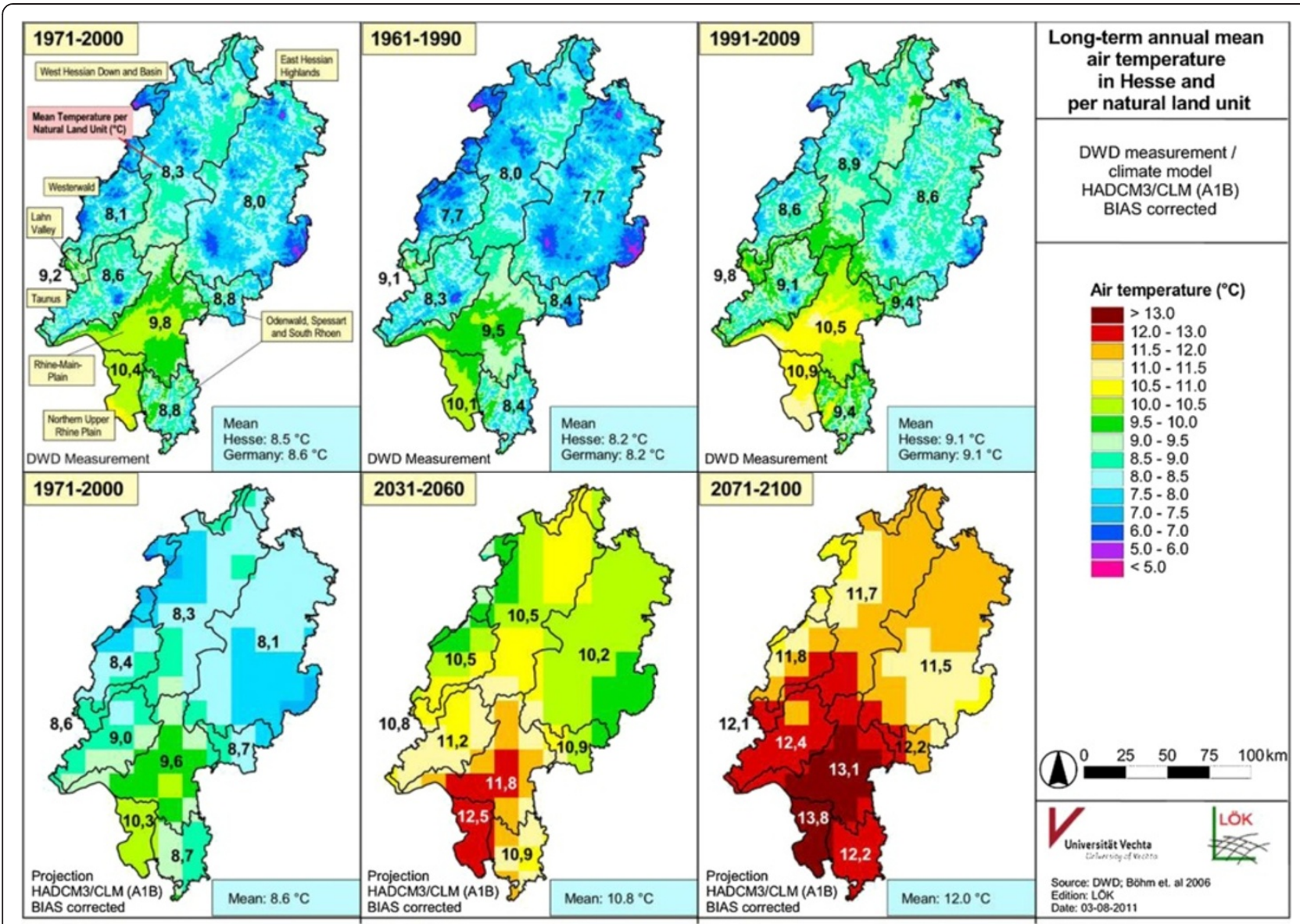

Figure 1 Annual mean air temperatures in Hesse. Above: measurements from 1961 to 2009 by DWD; below: projections for 1971 to 2000 , 2031 to 2060 and 2071 to 2100 for emission scenario A1B [29] by example of HADM3/COSMO-CLM climate model.

The respective regression model (Figure 5) explains $76 \%$ of the variance.

The bivariate statistical analysis revealed the statistical associations of at least medium strength $(r \geq 0.5)$ for more than $70 \%$ of the analysed phases in each of the three considered periods. More than $50 \%$ even showed a high correlation $(r \geq 0.7)$ between air temperatures and phenological onset. The result of the analysis corresponds with the findings for the past phenological development described in the 'Development of measured (1961 to 2009) and projected (2031 to 2060 and 2071 to 2100 ) air temperatures and phenological observations (1961 to 2009)' section: Almost all phases indicating an earlier beginning showed negative correlation coefficients. These findings corroborate, spatially differentiated, the hypothesis that air temperature is a significant driver for phenological development. However, phases with less intense shifts in the further course of the year ('Development of measured (1961 to 2009) and projected (2031 to 2060 and 2071 to 2100) air temperatures and phenological observations (1961 to 2009)' section) showed only weak correlation coefficients, especially in autumn. Eventually, two of those phases with shifts towards the end of the year (phases 73 and 226) revealed positive coefficients. This implies that high temperatures in autumn have reverse effects on these phases. Whereas high temperatures stimulate the beginning of spring and summer phases, they retard the onset of late autumn and winter phases [11].

The correlation analyses in this study considered spatial auto-correlation. The results of the respective computations according to [30] corroborated that autocorrelation considerably reduced the degrees of freedom. However, the correlations remained statistically significant $(p<0.01)$. For instance, no relevant differences were found for the significance of Spearman's $\left(r_{\mathrm{S}}=-0.858\right)$ and Person's $\left(r_{\mathrm{P}}=-0.873\right)$ correlation coefficients regarding the statistical association of apple bloom and air temperature from 1971 to 2000.

\section{Spatial patterns of measured (1961 to 2009) and projected (2031 to 2060 and 2071 to 2100 ) phenological phases}

Based on the results of the regression analysis ('Correlation between air temperature and plant phenology' 


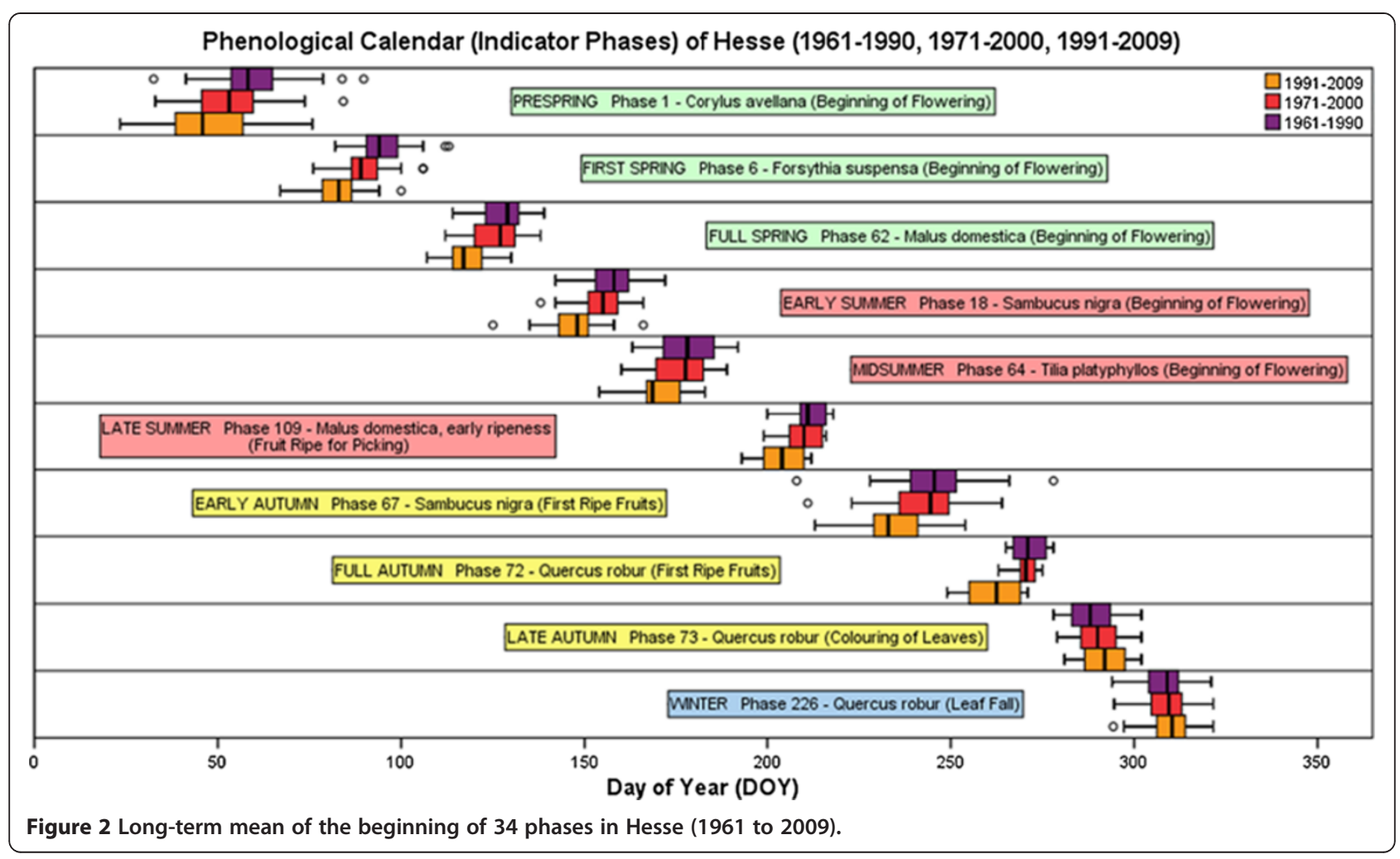

section), regression kriging was applied to 23 of the 35 investigated phases, indicating a correlation coefficient of at least 0.5 between air temperatures and phenological onset. The results of the phenological mapping are illustrated by the example of apple (Malus domestica) flowering. The upper row of Figure 6 depicts long-term phenological maps of Hesse for three past periods (1961 to 1990,1971 to 2000 and 1991 to 2009). Regarding these three maps, in Hesse, apple flowering began 8 days earlier in the period 1991 to 2009 compared to the period 1961 to 1990 (even 10 days when comparing only the averaged observations in these periods). As could be expected, topographical patterns were reflected in the phenological maps: Lower regions indicating rather warm temperatures (e.g. Rhine-Main river valleys) were characterized by early apple bloom. In comparison, mountainous regions (e.g. the Westerwald) showed latephase beginnings. These observations coincide with the regionally differentiated analysis based on the respective natural land units. On average, of the period 1971 to 2000, for instance, apple flowering occurred nearly 3 weeks earlier (April 21) in the Northern Upper Rhine Plain than that in the Eastern Hessian Highlands (May 10). Furthermore, the phenological development reflects the rise of air temperatures, as long-term phase shifts between the periods 1971 to 2000 and 1991 to 2009 are more distinct than those between the periods 1961 to
1990 and 1971 to 2000. The maximum shift between 1961 to 1990 and 1971 to 2000 lasted for 4 days (Taunus), whereas between the periods 1971 to 2000 and 1991 to 2009, the maximum shift lasted for 9 days (Westerwald). In summary, most regions of the Hessian uplands are affected by stronger shifts of the phase onset (e.g. Westerwald, Western Hessian Down and Basin, East Hessian Highlands), whereas valleys and lowlands in the south of Hesse are less affected.

The lower three maps of Figure 6 show, by example of one (HADCM3/CLM) of the four climate models considered, the projected future phenological development of apple bloom in Hesse for the future periods 2031 to 2060 and 2071 to 2100 as well as for the reference period 1971 to 2000. According to this climate model, apple flowering in Hesse will shift on average about 11 days towards the beginning of the year (from May 5 to April 24) between the periods 1971 to 2000 and 2031 to 2060, and another 7 days (April 17) compared to the period 2071 to 2100 . For some parts of Hesse, especially in the lowlands, apple flowering should begin even before April 10 in the period 2031 to 2060, and an average onset at the end of March and the very beginning of April is projected for the period 2071 to 2100. Depending on the respective climate model used in the examination at hand, the long-term mean shifts of apple bloom in Hesse range between 13 and 


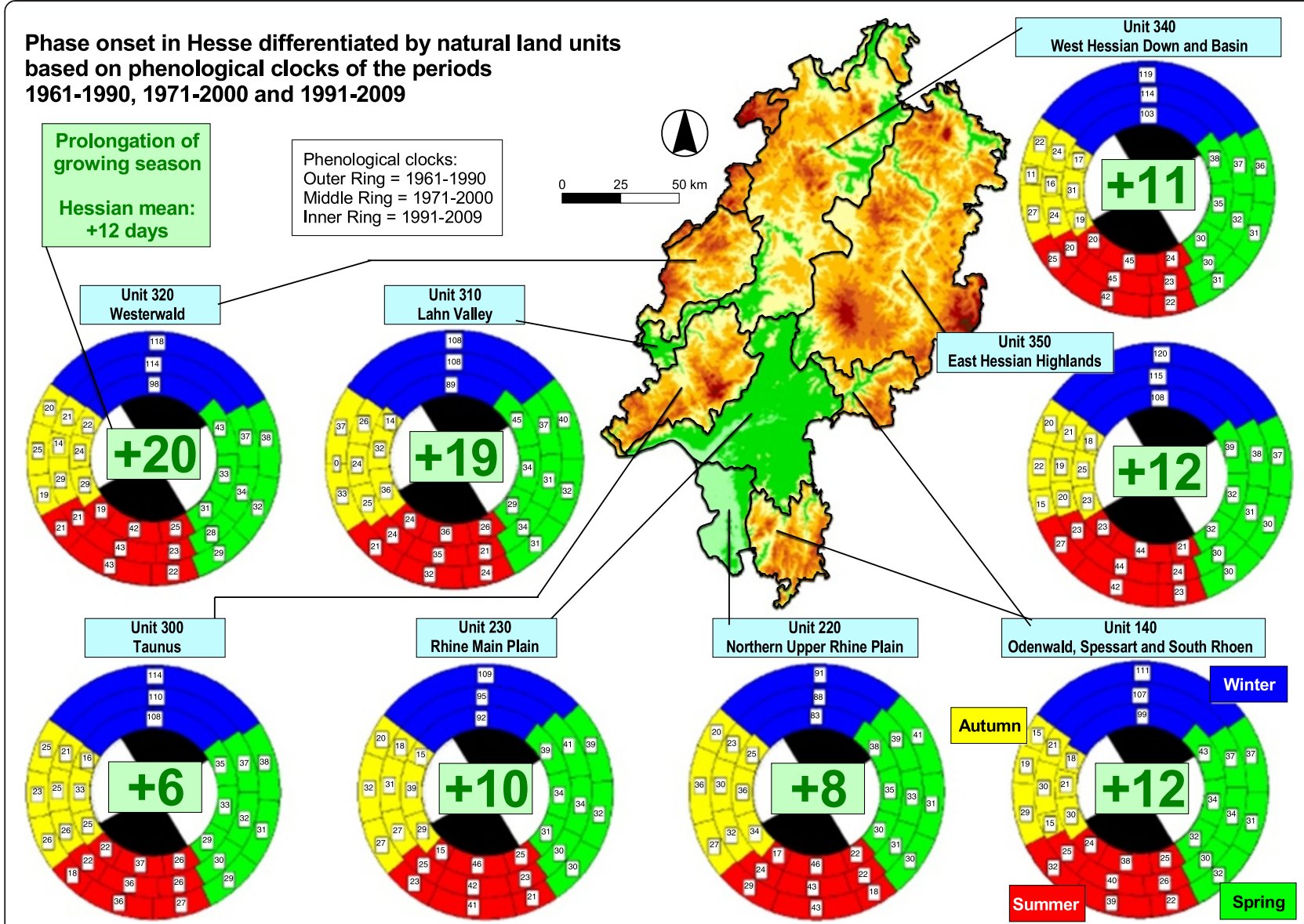

Figure 3 Landscape analysis of phenological onsets and growing seasons.

18 days when comparing the periods 1971 to 2000 and 2071 to 2100 .

Table 2 contains the shifts for 22 additional phases indicated as differences between the respective long-term means of the period 1961 to 1990 and the future period 2071 to 2100. The differences are all negative. Consequently, according to the results of the four climate models, the observed tendency of the past phenological development ('Development of measured (1961 to 2009) and projected (2031 to 2060 and 2071 to 2100) air temperatures and phenological observations (1961 to 2009)' section) will obviously continue until the end of the twenty-first century. The ECHAM5/COSMO-CLM-model (ECLM_K) and the REMO/UBA-Model (RUBA_K) are rather conservative, projecting mostly less-intense shifts, whereas shifts projected by HADM3/COSMO-CLM (HCLM_K) and WETTREG2010 (WETTR) are more distinct. Nevertheless, with only few exceptions, the shifts of the assessed phases for all the models between the periods 2071 to 2100 and 1961 to 1990 are at least twice as high as they are between 1991 to 2009 and 1961 to 1990 . For many phases, they are even three times higher or more. The most affected phases are due to occur about 1 month earlier and more (hazel flowering, 40 days earlier).

\section{Conclusions}

For analysing spatial patterns of the plant phenological development the geostatistical estimation of phenological surface maps is of remarkable importance, especially for those natural land units with small extents and a low number of observation sites. Several statistical values could prove the quality of the surface maps. Referring to the bivariate statistical analysis, the applied approach of using air temperature data of only those months that showed strong correlation between air temperature and phase onset instead of using annual mean air temperature data enabled powerful regression models.

The four different climate models used for projecting the future phase onsets showed different characteristics. As two of them projected rather moderate shifts until the end of the twenty-first century (ECHAM5/CLM and REMO/UBA), the two others (HADCM3/CLM and WETTREG 2010) projected stronger shifts. The 


\section{Mean temperatures March to June and onset of Apple flowering 1961-2009 in Hesse - Apple - Air temperature}

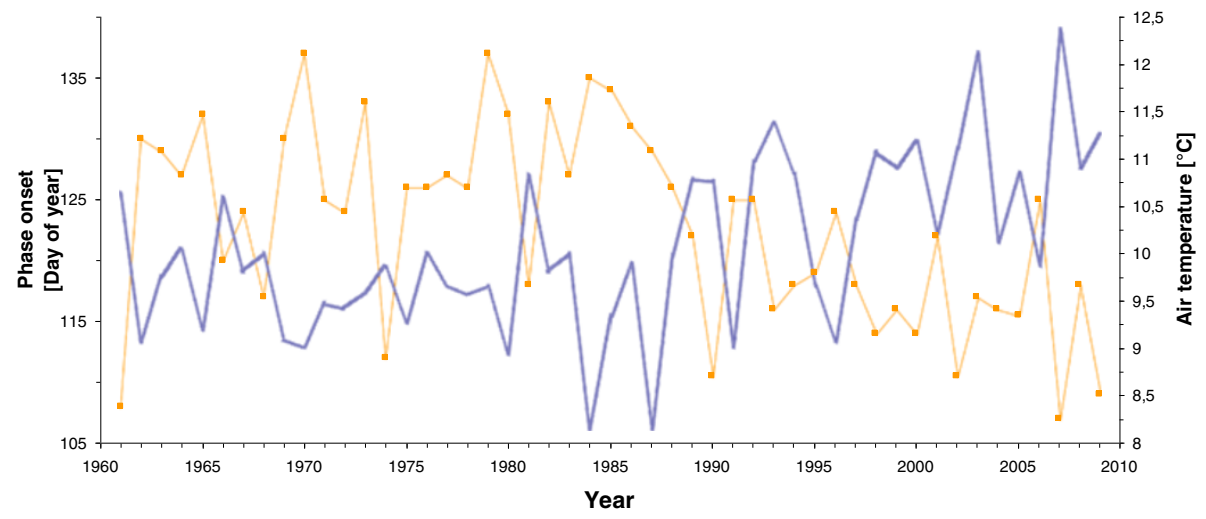

Figure 4 Mean temperatures (March to June) and onset of flowering of Malus domestica (1961 to 2009).

phenological monitoring should be complemented by a standardized metadata acquisition as done in the European moss survey [31] to promote the interpretation of phenological data. One further measure to support correctness, objectivity and reliability of plant phenological observations as well as the spatial density of monitoring networks is the use of digital repeat photography [32].

The application of regression models calculated for the years 1961 and 2009 to project changes in 2031 to 2100 may be misleading, since these constitute an extrapolation that may bias future impacts of climate change on the timing of phenological phases, given that the range of temperatures projected for the future would be significantly higher than those observed in the past and, thus, were not covered by the range of observational data used to derive the regression models. However, it should be recognized that, without any exception, according to basic and widely accepted knowledge of the philosophy of science, spatial and temporal extrapolations beyond time and space of measurements never can be fully justified in a strict sense of logical, inductive, reasoning ex ante [33-37]. Their validation needs empirical investigations ex post which are, in case of temporal extrapolations in terms of forecasts, prognoses and projections, impossible during the respective presence.

The presented approach allows revealing statistical relationships between air temperatures and phenological onsets and, by calculating residuals, indicates the extent of influence of other drivers affecting phenological development. Additionally, even though the residuals could not be explained in terms of identifying latent factors, the spatial structure of the residuals was considered within the regression kriging approach used for mapping recent and potential future spatial and temporal trends of phenological developments.

In this investigation, only one emission scenario (A1B) was considered. To establish a more comprehensive range of projections of the impacts of climate change, the study could have included other scenarios, particularly those that are more moderate compared to A1B as for instance B1 and B2. The results presented in this paper rely on a study which was conducted in the framework of the research program INKLIM-A founded by the federal state Hesse which brought together experts of several environmental sciences, including experts for climate modelling. Based on comprehensive knowledge represented in the research consortium, it was a unanimous decision that it would make no sense to consider the B1 scenario since the assumptions made for this scenario are meanwhile outdated. However, a wide range of temperature variation was considered by applying the four climate models reflecting, both, more conservative and more extreme temperature developments.

As documented in this investigation and in many studies across the world (e.g. America, Asia, Europe), the phenological records allow to estimate future trends of plant phenological development and related ecological processes for agriculture, forestry, human health and the global economy [22]. Thus, bio-monitoring of climate change using plant phenology as an indicator should further be refined [38]. We did not consider the potential impact of the geographic distribution of the phenological observations across Hesse, assuming that the observations were randomly distributed [39]. This assumption could be proved in a succeeding study. A refinement of the regression models presented in this study might be achieved by additional calculations for spatially and/or 
Table 1 Correlation coefficients (Pearson) between air temperature and phenological onset (1961 to 2009)

\begin{tabular}{|c|c|c|c|}
\hline \multirow[t]{2}{*}{ Phase } & \multicolumn{3}{|c|}{$r$ value } \\
\hline & 1961 to 1990 & 1971 to 2000 & 1991 to 2005 \\
\hline 1 & -0.79 & -0.79 & -0.71 \\
\hline 2 & -0.75 & -0.73 & -0.64 \\
\hline 6 & -0.85 & -0.88 & -0.82 \\
\hline 52 & -0.70 & -0.69 & -0.62 \\
\hline 7 & -0.73 & -0.77 & -0.72 \\
\hline 115 & -0.52 & 0.61 & -0.51 \\
\hline 62 & -0.82 & -0.87 & -0.83 \\
\hline 13 & -0.73 & -0.77 & -0.70 \\
\hline 15 & -0.83 & -0.86 & -0.83 \\
\hline 19 & -0.46 & -0.53 & -0.45 \\
\hline 18 & -0.75 & -0.77 & -0.74 \\
\hline 123 & -0.60 & -0.73 & -0.70 \\
\hline 20 & -0.56 & -0.65 & -0.63 \\
\hline 64 & -0.71 & -0.76 & -0.63 \\
\hline 100 & -0.73 & -0.73 & -0.61 \\
\hline 109 & -0.76 & -0.74 & -0.62 \\
\hline 65 & -0.11 & $-0.07^{\mathrm{a}}$ & $-0.06^{\mathrm{a}}$ \\
\hline 67 & -0.55 & 0.59 & -0.57 \\
\hline 177 & -0.39 & -0.38 & -0.33 \\
\hline 72 & -0.30 & -0.34 & -0.34 \\
\hline 68 & -0.38 & -0.40 & -0.43 \\
\hline 73 & 0.12 & 0.14 & 0.13 \\
\hline 94 & 0.12 & 0.16 & 0.23 \\
\hline 226 & - & - & 0.15 \\
\hline 54 & -0.82 & -0.86 & -0.84 \\
\hline 56 & -0.83 & -0.85 & -0.81 \\
\hline 60 & -0.84 & -0.88 & -0.84 \\
\hline 102 & -0.69 & -0.76 & -0.68 \\
\hline 103 & -0.65 & -0.74 & -0.60 \\
\hline 104 & -0.63 & -0.63 & -0.58 \\
\hline 107 & -0.51 & -0.63 & -0.51 \\
\hline 108 & -0.30 & -0.39 & -0.28 \\
\hline 171 & -0.44 & -0.51 & -0.62 \\
\hline 172 & -0.62 & -0.78 & -0.85 \\
\hline 205 & - & -0.78 & -0.36 \\
\hline
\end{tabular}

${ }^{a}$ Correlation is not significant.

timely defined clusters in Hesse/Germany [40] could prove that such specified models could be more effective than the general models and, thus, might be the basis for better plant phenology projections.

Climate change impacts on ecosystems are widely recorded in terms of phenological shifts of organisms worldwide. As shown in this investigation, changes in plant phenology evidently reflect a warming trend. Thus, phenology is useful as a primary tool for mapping early signs of ecosystem transitions under climate change across areas of large spatial extend. However, besides shifts in timing of phenological events, plants may also shift their geographical distribution towards more favourable climates or adapt to the altered local conditions. Shifts through phenotypic plasticity occur prior to and more rapidly than the more profound changes in species distribution and genetics [41] corroborated that different temperate plant genotypes require varying amount of heat energy for starting annual growth and reproduction due to adaptation and other ecological and evolutionary processes along climatic gradients, which is quantitatively reflected in the timing of phenophases. Accordingly, earlier timing indicates higher efficiency, i.e. less heat energy needed to trigger phenophase transitions.

Since temperature increase is expected to continue until the end of the twenty-first century, distinct effects on flora distribution are, thus, very likely and will result in changes in ecological processes, such as species migration or extinction, and in agricultural management. Cryophilic species are expected to move into northern latitudes and high altitudes, whereas thermophilic species are due to emigrate from southern regions into the north, repressing probably domestic species [42].

The phenological development of plants influences the mass and energy cycle of the biosphere [43]: Plant vegetative cycles determine the flows of matter, e.g. carbon dioxide and water, and energy between land surface and atmosphere. Additionally, canopy development and senescence are linked to seasonal changes in surface resistance and roughness, as well as the turbulent exchange of water and energy. Ma et al. [43] calculated that the leaf onset days for wheat, barley and rapeseed in Germany advanced by 1.6, 3.4 and 3.4 days per decade, respectively, during 1961 to 2000. This modelled trend of advanced onset days could be corroborated by observations from the International Phenology Gardens in Europe [44] reported that the temperature increase since 1980 has already lowered the worldwide wheat yields by $5.5 \%$, without considering the effect of increasing $\mathrm{CO}_{2}$ levels, and by $2.5 \%$ when considering $\mathrm{C}$-fertilization. Between 1981 and 2002, the average global wheat yield decreased by $88 \mathrm{~kg} / \mathrm{ha}$. Wheat in the developing countries is expected to suffer most among major crops from rising temperatures in low-latitude countries. Up to 2050, the wheat yield levels are expected to decrease by $5 \%$ to $9 \%$ for rain-fed systems. Thus, plant phenological observations are crucial not only for nature protection but also for agricultural management.

Using phenological maps as presented in this article, appropriate adaption strategies may be planned and implemented [45] in terms of, e.g. adjusting delineation, 


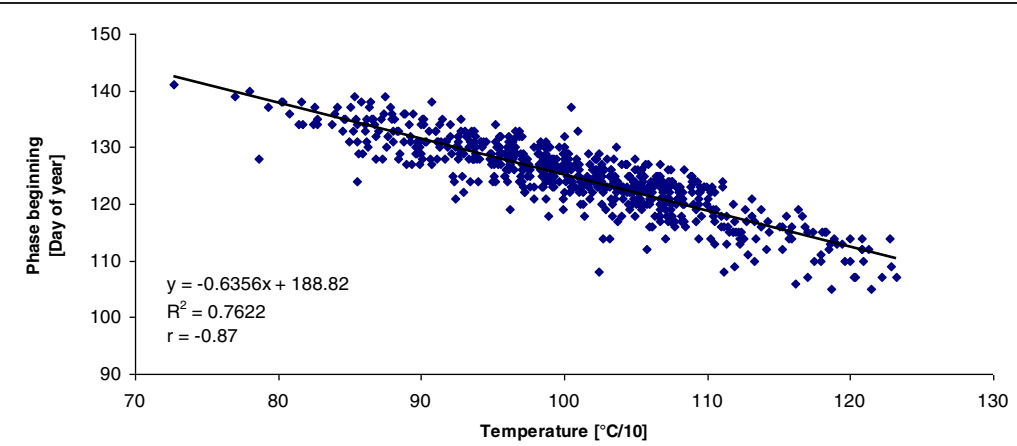

Figure 5 Regression model. This model is for the relation between mean temperatures (March to June) and onset of flowering of Malus domestica during the period 1971 to 2000.

shape and geographical position of protected areas $[46,47]$. In terms of agricultural management, the selection of crops and cultivars must be adjusted to the changed climatic conditions. Furthermore, farmers should cope with increased problems with insect pests potentially occurring due to increased air temperatures [39,48]. Another threat is the increasing risk of frost damage due to the earlier occurrence of phenological events [49].
Referring to resources management, irrigation in the summer will be necessary for larger areas and longer periods as precipitation is expected to decrease in Hesse during the vegetation period $[50,51]$. On the other hand, there are also positive effects of climate change: prolongation of the growing season [52] might lead to increased yields in some regions, and cultivation of new fruit varieties might be possible $[48,53,54]$.

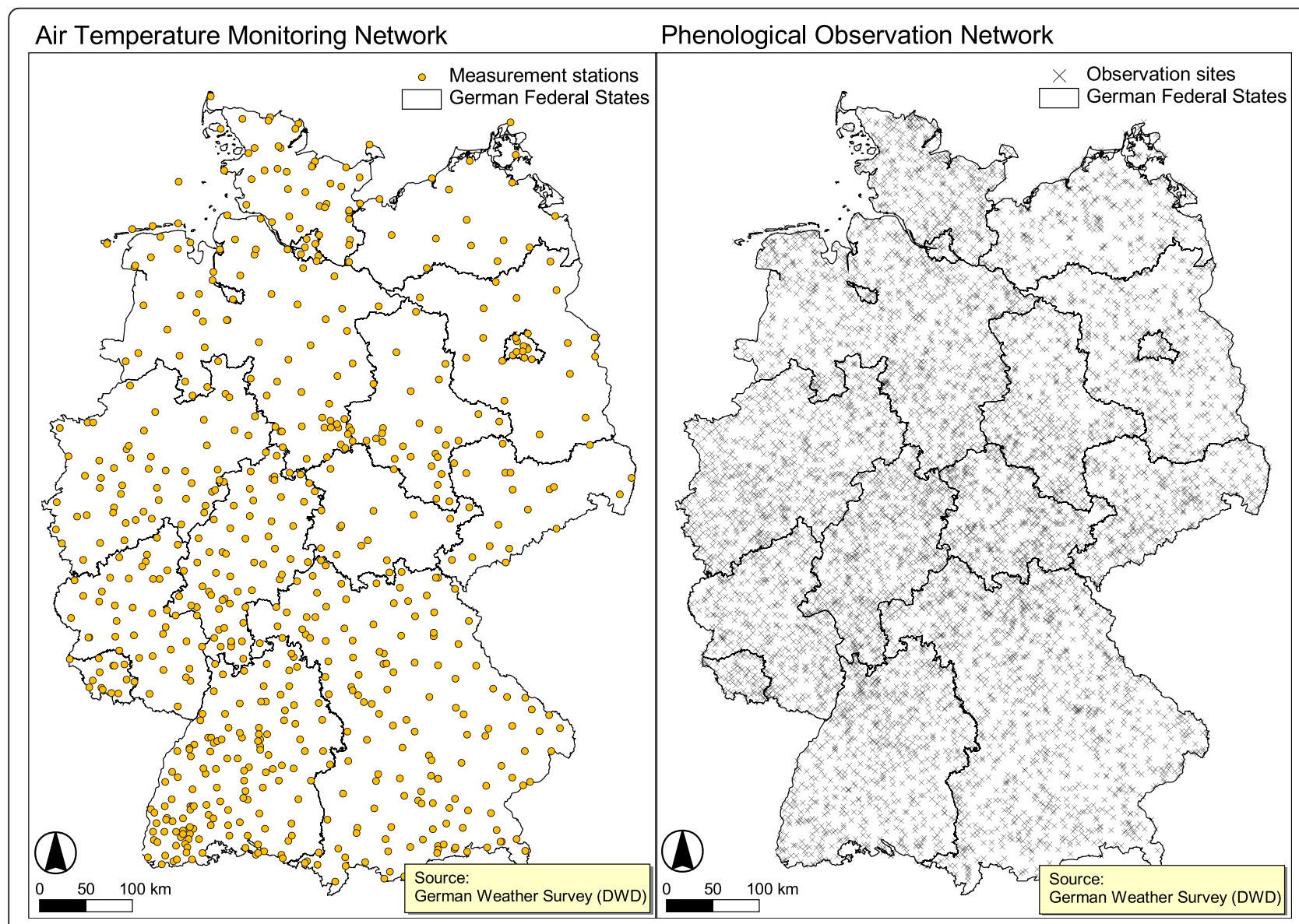

Figure 6 Long-term mean of the beginning of hazel flowering in Hesse (1961 to 2100). 
Table 2 Projected long-term mean shifts of 23 phases between 2071 to 2100 and 1961 to 1990

\begin{tabular}{|c|c|c|c|c|c|c|c|c|c|c|c|c|c|c|c|c|c|c|c|c|c|c|c|}
\hline Phase & 1 & 2 & 6 & 52 & 7 & 115 & 62 & 13 & 15 & 19 & 18 & 123 & 20 & 64 & 100 & 109 & 67 & 54 & 56 & 60 & 102 & 103 & 104 \\
\hline \multicolumn{24}{|c|}{$\begin{array}{l}\text { Differences (days) } \\
\text { between } 1991 \text { to } \\
2009 \text { and } 1961 \text { to } \\
1990 \text { (DWD- } \\
\text { observation) }\end{array}$} \\
\hline Observed & -14 & -9 & -11 & -10 & -8 & -6 & -10 & -8 & -9 & -7 & -10 & -4 & -7 & -9 & -8 & -5 & -11 & -6 & -7 & -7 & -12 & -9 & -10 \\
\hline \multicolumn{24}{|c|}{$\begin{array}{l}\text { Differences (days) } \\
\text { between } 2071 \text { to } \\
2100 \text { (projection) } \\
\text { and } 1961 \text { to } 1990 \\
\text { (DWD- } \\
\text { observation) }\end{array}$} \\
\hline ECLM_K & -30 & -22 & -23 & -13 & -16 & -7 & -16 & -14 & -15 & -12 & -17 & -12 & -15 & -19 & -25 & -26 & 27 & -15 & -15 & -19 & -26 & -21 & -24 \\
\hline HCLM_K & -32 & -23 & -26 & -18 & -19 & -11 & -20 & -17 & -18 & -14 & -19 & -12 & -15 & -20 & -25 & -27 & 29 & -17 & -18 & -21 & -25 & -21 & -24 \\
\hline RUBA_K & -33 & -24 & -25 & -13 & -17 & -7 & -15 & -14 & -15 & -12 & -16 & -11 & -14 & -17 & -22 & -23 & 25 & -15 & -14 & -19 & -23 & -18 & -20 \\
\hline WETTR_00 & -40 & -28 & -30 & -18 & -21 & -11 & -21 & -18 & -19 & -15 & -21 & -13 & -16 & -22 & -25 & -27 & 27 & -20 & -19 & -25 & -27 & -21 & -25 \\
\hline WETTR_05 & -40 & -28 & -30 & -16 & -20 & -10 & -19 & -18 & -17 & -13 & -19 & -11 & -15 & -21 & -26 & -26 & 27 & -19 & -17 & -23 & -26 & -21 & -25 \\
\hline
\end{tabular}

ECLM_K, HCLM_K, and RUBA_K WETTR are the climate models applied for the SRES scenario A1B [29]. ECHAM5/COSMO-CLM (bias corrected), HADM3/COSMO-CLM (bias corrected), REMO/UBA (bias corrected) and WETTREG2010 run_00 and run_55 [56-59]. DWD, Deutscher Wetterdienst (National Meteorological Service of the Federal Republic of Germany).

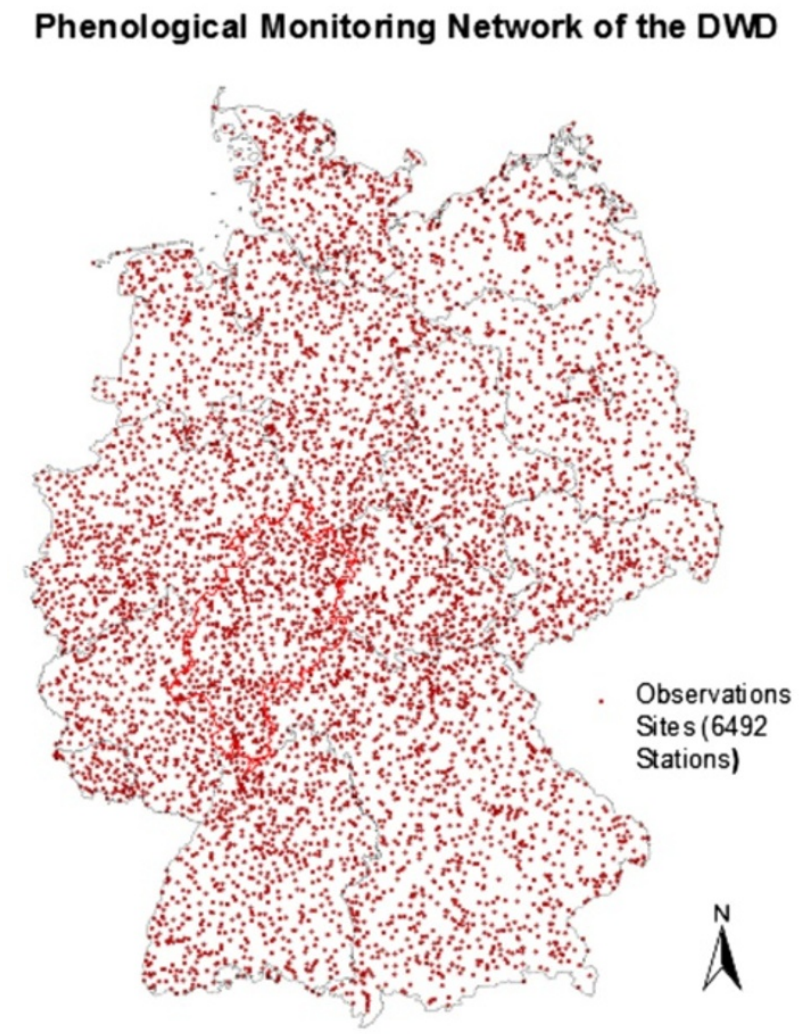

\section{Meteorological Monitoring Network of the DWD}

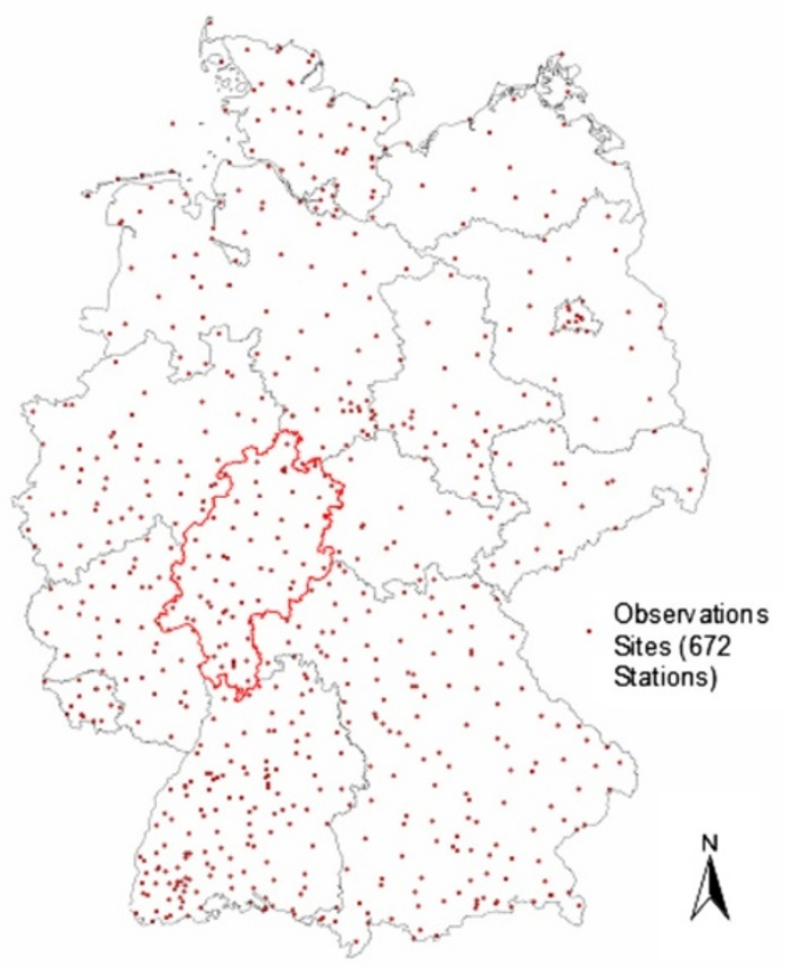




\section{Methods}

Data

For analysing and mapping the past phenological development, observations on plant phenology as well as temperature measurements collected by the German Weather Survey (Deutscher Wetterdienst (DWD)) from 1961 to 2009 (phenological data up to 2005) were used (Figure 7). The German phenological monitoring network comprises almost 6,500 sites (553 in Hesse), observing more than 270 phenophases of wildgrowing plants and crop plants (agricultural plants, fruits and vine).

Table 3 Phenological phases investigated (IDs, plant, phase and phenological season)

\begin{tabular}{|c|c|c|c|c|c|c|}
\hline Index & Plant & Phase & ID & Vegetation layers & Phase rank & Phenological season \\
\hline & Wild growing plants & & & & & \\
\hline 1 & Corylus avellana & Beginning of flowering & $\mathrm{B}$ & Shrub/tree layer & Indicator phase & Prespring \\
\hline 2 & Galanthus nivalis & Beginning of flowering & B & Herb layer & Alternative Phase & Prespring \\
\hline 6 & Forsythia suspensa & Beginning of flowering & B & Shrub layer & Indicator phase & First spring \\
\hline 52 & Ribes uva-crispa & Beginning of unfolding of leaves & $\mathrm{BO}$ & Shrub layer & Alternative phase & First spring \\
\hline 7 & Aesculus hippocastanum & Beginning of unfolding of leaves & $\mathrm{BO}$ & Tree layer & & First spring \\
\hline 115 & Anemone nemorosa & Beginning of flowering & B & Herb layer & & First spring \\
\hline 62 & Malus domestica & Beginning of flowering & B & Tree layer & Indicator phase & Full spring \\
\hline 13 & Quercus robur & Beginning of unfolding of leaves & $\mathrm{BO}$ & Tree layer & Alternative phase & Full spring \\
\hline 15 & Syringa vulgaris & Beginning of flowering & B & Shrub layer & & Full spring \\
\hline 19 & Alopecurus pratensis & Flowering general blossom & $A B$ & Herb layer & & Full spring \\
\hline 18 & Sambucus nigra & Beginning of flowering & B & Shrub layer & Indicator phase & Early summer \\
\hline 123 & Robinia pseudoacacia & Beginning of flowering & B & Tree layer & Alternative phase & Early summer \\
\hline 20 & Dactylis glomerata & Flowering general blossom & $A B$ & Herb layer & & Early summer \\
\hline 64 & Tilia platyphyllos & Beginning of flowering & B & Tree layer & Indicator phase & Midsummer \\
\hline 100 & Ribes rubrum & Fruit ripe for picking & $\mathrm{F}$ & Shrub layer & Alternative phase & Midsummer \\
\hline 109 & Malus domestica (early ripeness) & Fruit ripe for picking & $\mathrm{F}$ & Tree layer & Indicator phase & Late summer \\
\hline 65 & Calluna vulgaris & Beginning of flowering & B & Herb layer & & Late summer \\
\hline 67 & Sambucus nigra & First ripe fruits & $\mathrm{F}$ & Shrub layer & Indicator phase & Early autumn \\
\hline 177 & Rosa canina & First ripe fruits & $\mathrm{F}$ & Shrub layer & & Early autumn \\
\hline 72 & Quercus robur & First ripe fruits & $\mathrm{F}$ & Tree layer & Indicator phase & Full autumn \\
\hline 68 & Aesculus hippocastanum & First ripe fruits & $\mathrm{F}$ & Tree layer & Alternative phase & Full autumn \\
\hline 73 & Quercus robur & Colouring of leaves & BV & Tree layer & Indicator phase & Late autumn \\
\hline 226 & Quercus robur & Leaf fall & $\mathrm{BF}$ & Tree layer & Indicator phase & Winter \\
\hline \multirow[t]{2}{*}{94} & Triticum aestivum & Emergence & $\mathrm{AU}$ & Herb layer & Indicator phase & Winter \\
\hline & Fruits & & & & & \\
\hline 54 & Prunus avium & Beginning of flowering & B & Tree layer & & First spring \\
\hline 56 & Prunus cerasus & Beginning of flowering & B & Tree layer & & First spring \\
\hline 60 & Pyrus communis & Beginning of flowering & B & Tree layer & & First spring \\
\hline 102 & Prunus avium (early ripening) & Fruit ripe for picking & $\mathrm{F}$ & Tree layer & & Midsummer \\
\hline 103 & Prunus avium (late ripening) & Fruit ripe for picking & $\mathrm{F}$ & Tree layer & & Midsummer \\
\hline 104 & Prunus cerasus & Fruit ripe for picking & $\mathrm{F}$ & Tree layer & & Midsummer \\
\hline 107 & Pyrus communis (early ripening) & Fruit ripe for picking & $\mathrm{F}$ & Tree layer & & Early autumn \\
\hline \multirow[t]{2}{*}{108} & Pyrus communis (late ripening) & Fruit ripe for picking & $\mathrm{F}$ & Tree layer & & Full autumn \\
\hline & Vine & & & & & \\
\hline 171 & vine (Muller-Thurgau) & Beginning of sprouting & A & Shrub layer & & First spring \\
\hline 172 & vine (Muller-Thurgau) & Beginning of flowering & B & Shrub layer & & Early summer \\
\hline 205 & vine (Muller-Thurgau) & Grape gathering & $\mathrm{L}$ & Shrub Layer & & Full autumn \\
\hline
\end{tabular}


The phenological observations were conducted two or three times a week within a defined area by volunteers according to a guideline [55]. For the analysis at hand, 35 phases were selected. They comprise so-called indicator phases for different phenological seasons and respective alternative phases [55]. Additional phases were selected to describe the phenology of fruits and vine plants representing high economic importance for fruit growers (Table 3).

The phenological data sets were provided as vector data (point layer); climate data were provided as grid data sets with a spatial resolution of $1 \times 1 \mathrm{~km}^{2}$. For mapping the potential future phenological development during the years 2031 to 2060 and 2071 to 2100, the results for the SRES A1B emission scenario [29] processed by four models (REMO/UBA, ECHAM5/ COSMO-CLM, HADM3/COSMO-CLM and WETTREG2010 (two runs)) were used. The modelled temperature maps were provided as grid data with a spatial resolution of $20 \times 20 \mathrm{~km}$ [56-59]. Before statistical analysis ('Statistical analyses' section), the phenology data were checked for quality by use of three approaches, testing whether (1) each observation site covers at least $90 \%$ of the respective long-term period (1961 to 1990, 1971 to 2000 and 1991 to 2005) (temporal representativeness), (2) the onset at one site differed conspicuously from the average beginning at the surrounding the observation sites (neighbourhood analysis) and (3) the onset was remarkably early or late compared to the average (outlier analysis). This quality control complemented the quality check conducted routinely by the DWD before offering the data. The plausibility analysis finally resulted in the exclusion of 100 long-term datasets [60].

\section{Statistical analyses}

After quality control as described in the 'Data' section, the meteorological and phenological data were analysed by descriptive statistics to detect the trends in the past phenological development. After having proved the normal distribution of the data, the strength of the statistical association between air temperature and each of the respective phenophase for the periods 1961 to 1990 , 1971 to 2000 and 1991 to 2009 was computed by the use of bivariate correlation analysis (Pearson's productmoment correlation coefficients) and modelled by the use of linear regression analysis [61]. To enhance the reliability of the results, the computations comprised temperature and phenological data covering the whole territory of Germany instead of only those of Hesse. The phenological point data and temperature grids were intersected within a GIS to estimate the air temperature values for each phenological observation site.

In environmental systems, auto-correlation is a widespread phenomenon $[62,63]$ which, in statistics, is defined as the similarity of, or correlation between, the values of a process at neighbouring points in time or space. Positive auto-correlation means that the individual observations contain information which is part of the other, timely or spatial neighbouring, observations. Subsequently, the effective sample size is less than the number of the realized observations. Negative auto-correlation can have the opposite effect, thus making the effective sample larger than the realized sample. Therefore, auto-correlation can have several implications for, e.g. statistical inference testing and regression analysis [64]. It could be shown that positive spatial auto-correlation enhances type-I errors, so parametric statistics such as Pearson correlation coefficients are declared significant when they should not be [65]. Thus, in this investigation, spatial auto-correlation was considered in the correlation analyses according to [30].

The regression analysis was based only on those months showing the strongest correlation between air temperatures and the respective phenological onset instead of only using annual or monthly mean air temperatures. Accordingly, long-term mean temperatures were calculated for each sequence of these related months (e.g. averaged temperatures from March to June for the period 1971 to 2000 ) and then related to the respective phenological observations for each of the three periods. The resulting $r$ values were classified as follows: $r<0.20$, very low correlation; $0.20 \geq r \geq-0.49$, low; $0.50 \geq r \geq 0.69$, medium; $0.70 \geq r \geq 0.89$, high; and $r \geq 0.9$, very high correlation [66].

For those phases showing a significant and at least medium correlation $(r \geq 0.5)$, phenological maps for each period (1961 to 1990, 1971 to 2000, 1991 to 2009, 2031 to 2060 and 2071 to 2100 ) were calculated in a GIS by regression kriging $[67,68]$. The regression equation derived for each phase and period was thereby applied to the long-term mean temperature grids to calculate a surface map for the respective phenophase. Then, these regression maps were added by kriging maps depicting the spatial structure of the residuals of the regression models based on autocorrelation functions determined by use of variogram analysis. The potential future phenological development was estimated by applying the regression equations of the reference period 1971 to 2000 to the air temperature grids of the periods 2031 to 2060 and 2071 to 2100 for each of the four climate projections as calculated by the use of REMO/UBA, ECHAM5/ COSMO-CLM, HADM3/COSMO-CLM and WETTREG2010 [56-59]. Additionally, the past and potential future phenological developments were spatially differentiated by intersection of the respective phenological maps with a map on the natural land units [69] of Hesse. 


\section{Competing interests}

The authors declare that they have no competing interests.

\section{Authors' contributions}

WS drafted the manuscript and led the project. SS carried out the statistical analyses, and GS participated in its design and coordinated the investigations. All authors read and approved the final manuscript.

Received: 16 October 2013 Accepted: 24 January 2014

Published: 25 February 2014

\section{References}

1. Ahas R, Aasa A: The effects of climate change on the phenology of selected Estonian plant, bird and fish populations. Int J Biometeorol 2006, 51:17-26.

2. Holopainen J, Helama S, Lappalainen H, Gregow H: Plant phenological records in northern Finland since the $18^{\text {th }}$ century as retrieved from databases, archives and diaries for biometeorological research. Int $J$ Biometeorol 2013, 57:423-435.

3. Parmesan C: Influences of species, latitudes and methodologies on estimates of phenological response to global warming. Global Change Biol 1860-1872, 2007:13.

4. Rosenzweig C, Casassa G, Karoly DJ, Imeson A, Liu C, Menzel A, Rawlins S, Root TL, Seguin B, Tryjanowski P: Assessment of observed changes and responses in natural and managed systems. In Climate Change 2007: Impacts, Adaptation and Vulnerability. Contribution of Working Group II to the Fourth Assessment Report of the Intergovernmental Panel on Climate Change. Edited by Parry ML, Canziani OF, Palutikof JP, van der Linden PJ, Hanson CE. Cambridge: Cambridge University Press; 2007:79-131.

5. van Bodegom PM, Verboom J, Witte JPM, Vos CC, Bartholomeus RP, Geertsema W, Cormont A, van der Veen M, Aerts R: Synthesis of ecosystem vulnerability to climate change in the Netherlands shows the need to consider environmental fluctuations in adaptation measures. Reg Environ Change 2013. doi:10.1007/s10113-013-0511-x.

6. Brown I: Influence of seasonal weather and climate variability on crop yields in Scotland. Int J Biometeorol 2012, 57:605-614.

7. Li Z, Yang P, Tang H, Wu W, Yin H, Liu Z, Zhang L: Response of maize phenology to climate warming in Northeast China between 1990 and 2012. Reg Environ Change 2014, 14(1):39-48. doi:10.1007/s10113-013-0503-x.

8. Morren C: Le globe, le temps et la vie. Bulletins de l'Académieroyale des Sciences, des Lettres et des Beaux-Arts de Belgique 1849, 2:660-684.

9. Demarée GR, Rutishauser T: From "periodical observations" to "anthochronology" and "phenology"--the scientific debate between AdolpheQuetelet and Charles Morren on the origin of the word "phenology". Int J Biometeorol 2012, 55:753-761.

10. Schnelle F: Pflanzen-Phänologie. Leipzig: Geest \& Portig; 1955.

11. Seyfert F: Phänologie. Wittenberg: Ziemsen; 1960.

12. Lieth H: (Ed): Phenology and Seasonality Modelling. New York: Springer; 1974.

13. Schwartz MD: Phenology. An Integrative Environmental Science. Dordrecht: Kluwer; 2003.

14. Clealand EE, Allen JM, Crimmins TM, Dunne JA, Pau S, Travers SE, Zavaleta ES, Wolkovich EM: Phenological tracking enables positive species responses to climate change. Ecology 2012, 93(8):1765-1771.

15. Cook BI, Wolkovichc EM, Parmesan C: Divergent responses to spring and winter warming drive community level flowering trends. Proc Natl Acad Sci USA 2012, 109(23):9000-9005.

16. Ellwood ER, Temple SA, Primack RB, Bradley NL, Davis CC: Record-breaking early flowering in the Eastern United States. PLOS ONE 2013, 8(1):e53788. doi:10.1371/journal.pone.0053788.

17. Pau S, Wolkovich EM, Cook BI, Davies JT, Kraft NJB, Blomgren K, Betancourt $J \mathrm{~L}$, Clealand EE: Predicting phenology by integrating ecology, evolution and climate science. Glob Chang Biol 2011, 17:3633-3643.

18. Chmielewski FM, Müller A, Küchler W: Possible impacts of climate change on natural vegetation in Saxony (Germany). Int J Biometeorol 2005, 50:96-104.

19. Cook BI, Wolkovich EB, Davies TJ, Ault TR, Betancourt JL, Allen JM, Bolmgren K, Cleland EE, Crimmins TM, Kraft NJB, Lancaster LT, Mazer SJ, McCabe GJ, McGill BJ, Parmesan C, Pau S, Regetz J, Salamin N, Schwartz MD, Travers SE: Sensitivity of spring phenology to warming across temporal and spatial climate gradients in two independent databases. Ecosystems 2012, 15:1283-1294.
20. Črepinšek Z, Štampar F, Kajfež-Bogataj L, Solar A: The response of Corylus avellana $\mathrm{L}$. phenology to rising temperature in north-eastern Slovenia. Int J Biometeorol 2012, 56:681-694.

21. Chuine I, Cambon G, Comtois P: Scaling phenology from local to the regional level: advances from species-specific phenological models. Global Change Biol 2000, 6(8):943-952.

22. Khanduri VP, Sharma CM, Singh SP: The effects of climate change on plant phenology. Environmentalist 2008, 28:143-147.

23. Schmidt G, Holy M, Pesch R, Schröder W: Changing plant phenology in Germany due to the effects of global warming. Int J Climate Change 2010, 2(2):73-84.

24. Schröder W, Pesch R, Schmidt G, Englert C: Analysis of climate change affecting German forests by combination of meteorological and phenological data within a GIS environment. Sci World J 2007, 7(S1):84-89.

25. Schröder W, Schmidt G, Hasenclever J: Geostatistical analysis of data on air temperature and plant phenology from Baden-Württemberg (Germany) as a basis for regional scaled models of climate change. Environ Monit Assess 2006, 130(1-3):27-43.

26. Kreeb KH: Methoden zur Pflanzenökologie und Bioindikation. Stuttgart: Fischer; 1990

27. Braun P, Brügger R, Bruns E, Clever J, Estreguil C, Flechsig M, De Groot RS, Grutters M, Harrewijn J, Jeanneret F, Martens P, Menne B, Menzel A, Sparks T: European Phenology Network. Nature's Calendar on the Move. Wageningen University: Wageningen; 2003

28. Gebhardt H, Rammert U, Schröder W, Wolf H: Klima-Biomonitoring: Nachweis des Klimawandels und dessen Folgen für die belebte Umwelt. Umweltwiss Schadst Forsch 2010, 22:7-19.

29. Intergovernmental Panel on Climate Change (IPCC): Climate Change 2007: Synthesis Report. Geneva: IPCC; 2007.

30. Dutilleul P: Modifying the t-test for assessing the correlation between two spatial processes. Biometrics 1993, 49:305-314.

31. Pesch R, Schröder W: Assessment of metal accumulation in mosses by combining metadata, statistics and GIS. Nova Hedwigia 2006, 82(3-4):447-466

32. Crimmins MA, Crimmins TM: Monitoring plant phenology using digital repeat photography. Environ Manage 2008, 41:949-958.

33. Gardner RH, Kemp WM, Kennedy VS, Petersen JE: (Eds): Scaling Relations in Experimental Ecology. New York: Columbia University Press; 2001.

34. Hume D: An Enquiry Concerning Human Understanding. London; 1748.

35. Ecological Scale: Theory and Applications. Edited by Peterson DL, Parker VT. New York: Columbia University Press; 1998

36. Schneider DC: Quantitative Ecology: Spatial and Temporal Scaling. San Diego: Academic; 1994

37. Wiens JA: Spatial scaling in ecology. Funct Ecol 1989, 3:385-397.

38. Englert C: Plant phenology in Germany between 1951 and 2005: data quality assurance and bioindication of climate change. In PhD thesis. University of Vechta; 2010.

39. van Vliet AJH, Bron WA, Mulder S, van der Slikke W, Ode B: Observed climate-induced changes in plant phenology in the Netherlands. Reg Environ Change 2013. doi:10.1007/s10113-013-0493-8.

40. Oteros J, García-Mozo H, Hervás-Martínez C, Galán C: Year clustering analysis for modelling olive flowering phenology. Int J Biometeorol 2013, 57:545-555.

41. Liang L, Schwartz MD: Testing a growth efficiency hypothesis with continental-scale phenological variations of common and cloned plants. Int J Biometeorol 2014. doi:10.1007/s00484-013-0691-6.

42. Theurillat JP, Guisan A: Potential impact of climate change on vegetation in the European Alps: a review. Clim Change 2001, 50:77-109.

43. Ma S, Churkina G, Trusilova K: Investigating the impact of climate change on crop phenological events in Europe with a phenology model. Int $J$ Biometeorol 2012, 56:749-763.

44. Shiferaw B, Smale M, Braun H-J, Duveiller E, Reynolds M, Muricho G: Crops that feed the world 10. Past successes and future challenges to the role played by wheat in global food security. Food Sec 2013, 5:291-317.

45. Elith J, Leathwick J: Species distribution models: ecological explanation and prediction across space and time. Annu Rev Ecol Evol 2009, 40:677-697.

46. Mawdsley JR, O'Malley R, Ojima DS: A review of climate-change adaptation strategies for wildlife management and biodiversity conservation. Conserv Biol 2009, 23(5):1080-1089. 
47. Milad M, Schaich $H$, Bürgi M, Konold W: Climate change and nature conservation in Central European forests: a review of consequences, concepts and challenges. Forest Ecol Manage 2011, 261:829-843.

48. Bindi $\mathrm{M}$, Olesen JE: The responses of agriculture in Europe to climate change. Reg Environ Change 2011, 11:151-158.

49. Inouye DW: The ecological and evolutionary significance of frost in the context of climate change. Ecol Lett 2000, 3:457-463.

50. Enke W: Anwendung eines Statistischen Regionalisierungsmodells auf das Szenario B2 des ECHAM4 OPYC3 Klima-Simulationslaufes bis 2050 zur Abschätzung Regionaler Klimaänderungen für das Bundesland Hessen. Hessisches Landesamt für Umwelt und Geologie: Wiesbaden; 2003.

51. Enke W: Erweiterung des Simulationszeitraumes der Wetterlagenbasierten Regionalisierungsmethode auf der Basis des ECHAM4-OPYC3 Laufes für die Dekaden 2011/2020 und 2051/2100, Szenario B2. Hessisches Landesamt für Umwelt und Geologie: Wiesbaden; 2004.

52. Henniges $Y$, Danzeisen $H$, Zimmermann R-D: Regionale Klimatrends mit Hilfe der Phänologischen Uhr, Dargestellt am Beispiel Rheinland-Pfalz. Umweltwiss Schadst Forsch 2005, 17(1):28-34

53. Priess JA, Heistermann M, Schaldach R, Onigkeit J, Mimler M, Trinks D, Alcamo J: Klimawandel und Landwirtschaft in Hessen: Mögliche Auswirkungen des Klimawandels auf Landwirtschaftliche Erträge. In Abschlussbericht für den Bereich Landwirtschaft, InKlim 2012-Integriertes Klimaschutzprogramm Baustein II: Klimawandel und Klimafolgen in Hessen. Kassel: Universität Kassel; 2005. http://klimawandel.hlug.de/fileadmin/ dokumente/klima/inklim/endberichte/landwirtschaft.pdf.

54. Streitfert A, Grünhage L, Jäger H-J: Klimawandel und Pflanzenphänologie in Hessen. Giessen: InstitutfürPflanzenökologie, Justus-Liebig-Universität Giessen; 2005.

55. Deutscher Wetterdienst (DWD): Anleitung für die Phänologischen Beobachter des Deutschen Wetterdienstes (BAPH). Offenbach am Main: DWD; 1991.

56. Böhm U, Kücken M, Ahrens W, Block A, Hauffe D, Keuler K, Rockel B, Will A: CLM - the climate version of LM: brief description and long-term applications. COSMO Newsletter 2006, 6:225-235.

57. Jacob D, Göttel H, Kotlarski S, Lorenz P, Sieck K: Klimaauswirkungen und Anpassung in Deutschland —Phase 1: Erstellung regionaler Klimaszenarien für Deutschland. Forschungsbericht 20441 138, UBA-FB 000969. Regionaler Klimaatlas Deutschland: Dessau; 2008.

58. Keuler K, Lautenschlager M: ClimateSimulationswith CLM. Climate of the 20th Century run No. 1, 1960-2000, Data Stream 2 und Scenario A1B run No. 1, 2001-2100, European Region, MPI-M/MaD. Hamburg: Max-Planck Institut für Meteorologie; 2006. http://cera-www.dkrz.de/WDCC/ui/BrowseExperiments. jsp?proj=CLM_regional_climate_model_runs].

59. Kreienkamp F, Spekat A, Enke W: Ergebnisse eines Regionalen Szenarienlaufs für Deutschland mit dem Statistischen Modell WETTREG2010. Report. CEC Potsdam: Potsdam; 2010

60. Schröder W, Schmidt G, Schönrock S: Landesweite untersuchungen zu beobachteten und zukünftig zu erwartenden änderungen der phänologie von wild- und kulturpflanzen in Hessen und deren implikationen für die forst- und landwirtschaft - klimawandel und pflanzenphänologie in Hessen. In Abschlussbericht für das Fachzentrum Klimawandel Hessen, Hessisches Landesamt für Umwelt und Geologie. Vechta, Wiesbaden; 2012.

61. Bahrenberg G, Giese E: Statistische Methoden und ihre Anwendung in der Geographie. Stuttgart: Teubner; 1975.

62. Brown DG, Aspinall T, Bennett DA: Landscape models and explanation in landscape ecology - a space for generative landscape science? Prof Geograph 2006, 58:369-382.

63. Legendre P: Spatial autocorrelation: trouble or new paradigm? Ecology 1993, 74:1659-1673.

64. Dale MRT, Fortin M-J: Spatial autocorrelation and statistical tests: some solutions. J Agr Biol Environ Stat 2009, 14:188-206.

65. Fortin J-M, Payette $S$ : How to test the significance of the relation between spatially autocorrelated data at the landscape scale: a case study using fire and forest maps. Ecosci 2001, 9:213-218.

66. Hagl S: Schnelleinstieg Statistik: Daten Erheben, Analysieren, Präsentieren Haufe-Lexware: München; 2008

67. Odeh IOA, McBratney AB, Chittleborough DJ: Further results on prediction of soil properties from terrain attributes: heterotopic cokriging and regression-kriging. Geoderma 1995, 67:215-226.
68. Zirlewagen $D$, Raben $G$, Weise M: Zoning of forest health conditions based on a set of soil, topographic and vegetation parameters. Forest Ecol Manage 2007, 248:43-55.

69. Meynen E, Schmithüsen J: Handbuch der naturräumlichen Gliederung Deutschlands. Selbstverlag der Bundesanstaltfür Landeskunde: Remagen; 1953-1962.

doi:10.1186/2190-4715-26-5

Cite this article as: Schröder et al:: Modelling and mapping of plant phenological stages as bio-meteorological indicators for climate change. Environmental Sciences Europe 2014 26:5.

\section{Submit your manuscript to a SpringerOpen ${ }^{\odot}$ journal and benefit from:}

- Convenient online submission

- Rigorous peer review

- Immediate publication on acceptance

- Open access: articles freely available online

- High visibility within the field

- Retaining the copyright to your article

Submit your next manuscript at $\gg$ springeropen.com 